ROCZNIKI HUMANISTYCZNE

Tom LXIX, zeszyt $10 \quad-\quad 2021$

DOI: https://doi.org/10.18290/rh216910-2

\title{
SŁOWOTWÓRSTWO A SKŁADNIA W NAUCZANIU JĘZYKA POLSKIEGO JAKO OBCEGO CZEŚ́Ć 1. WPROWADZENIE TEORETYCZNE
}

Adekwatny model kształcenia kompetencji języka obcego wymaga $[\ldots]$ nieustannej współpracy glottodydaktyki i językoznawstwa. (Florczak 22)

\section{WPROWADZENIE}

Słowotwórstwo w glottodydaktyce polonistycznej jest obecnie postrzegane nie tylko gramatycznie, jako część morfologicznego poziomu języka, ale także w ścisłym związku $\mathrm{z}$ poziomem leksykalnym (Pastuchowa, „Słowotwórstwo"; Seretny i Stefańczyk). Dlatego postuluje się nauczanie słowotwórstwa zarówno w ramach komponentu gramatycznego, w celu poznawania budowy i znaczenia formacji słowotwórczych, jak i leksykalnego, skoncentrowanego na rozwijaniu umiejętności posługiwania się derywatami oraz obserwowaniu mechanizmów słowotwórczych „w działaniu” (Seretny i Stefańczyk 55-56; Pastuchowa, „Rola słowotwórstwa” 14) ${ }^{1}$. Niniejsze opracowanie, obejmujące dwa komplementarne teksty pod wspólnym tytułem głównym „Słowotwórstwo a składnia w nauczaniu języka polskiego jako obcego", wpisuje się w rozważania o modyfikowaniu podejścia do słowotwórstwa w nauczaniu języka polskiego jako obcego. Zwraca bowiem uwagę na jeszcze jedno systemowe i komunikacyjne uwikłanie słowotwórstwa,

Dr hab. Malgorzata GęBKa-WolaK - Uniwersytet Mikołaja Kopernika w Toruniu, Instytut Językoznawstwa, Katedra Języka Polskiego; e-mail: mge@umk.pl. ORCID: https://orcid.org/ 0000-0003-4587-496X.

${ }^{1} \mathrm{~W}$ nowszych opracowaniach glottodydaktycznych podejmowane są także inne wątki z zakresu słowotwórstwa (Gaze, „Związki między słowotwórstwem” i „Rola słowotwórstwa”; Janowska, „O swoistości derywacji”, „Z pogranicza słowotwórstwa” i „Złożoność derywacji”). 
a mianowicie powiązanie budowy słowotwórczej jednostek z ich związkami składniowymi.

Celem tekstu jest syntetyczne przedstawienie podstawowych informacji na temat związków składni i słowotwórstwa w polszczyźnie, ze szczególnym uwzględnieniem dziedziczenia wymagań składniowych przez jednostki powiązane słowotwórczo. Tak przygotowany materiał językoznawczy stanowi podstawę do działań na gruncie dydaktycznym, których wskazanie jest z kolei zadaniem opracowania Aleksandry Walkiewicz, zamieszczonego w tym numerze Roczników Humanistycznych (ss. 41-56). Tym samym niniejszy tekst dostarcza uporządkowanej wiedzy o wybranym fragmencie systemu językowego, kolejny - wskazówek, jak wiedzę tę najpierw przetworzyć na potrzeby nauczania, a następnie prezentować na zajęciach języka polskiego jako obcego. Należy zaznaczyć, że zagadnienie związków słowotwórstwa i składni nie jest nowe ani na gruncie językoznawstwa, ani w glottodydaktyce. Wydaje się jednak, że dydaktyczny potencjał wybranego tematu nie został jeszcze w pełni wykorzystany. W opracowaniach kierowanych do uczących się języka polskiego jako obcego znajdujemy jedynie informacje podstawowe, często też rozproszone, ponadto pozbawione eksplicytnego komentarza, co utrudnia zdanie sobie sprawy ze skali i zróżnicowanej regularności zjawiska ${ }^{2}$. Wiedza na temat współdziałania podsystemów słowotwórczego i składniowego, zasadniczo za pośrednictwem podsystemu leksykalnego, ułatwia budowanie zdań i dłuższych wypowiedzi. Z kolei uczącym się, którzy chcą zdobyć certyfikat znajomości języka polskiego, może się także przydać na egzaminie.

Artykuły będące efektem współpracy językoznawcy z glottodydaktykiem zostały zaplanowane tak, by mniej doświadczonym lektorom pokazać, w jaki sposób w ramach nauczania polszczyzny korzystać z wiedzy językoznawczej. Przedstawiają bowiem proces dostosowania wiedzy teoretycznej do potrzeb dydaktyki. Punktem wyjścia, którego efektem jest pierwszy tekst, jest zapoznanie się z literaturą językoznawczą, wybór, uzupełnienie i uporządkowanie danych na interesujący nas temat oraz ich syntetyczna prezentacja. Następny etap - naszkicowany w tekście drugim - polega na ustaleniu, w jaki sposób w kontekście obowiązujących programów nauczania oraz

\footnotetext{
${ }^{2}$ Zagadnienie słowotwórstwa a składni w programie nauczania języka polskiego jako obcego oraz w podręcznikach omawia, jak wspomniano, A. Walkiewicz w niniejszym numerze Roczników Humanistycznych. W tym miejscu ograniczymy się do zasygnalizowania, że zgodnie z naszą wiedzą najwięcej informacji teoretycznych o powiązaniach słowotwórczo-składniowych zawiera Gramatyka języka polskiego dla cudzoziemców Z. Kalety (96, 102, 320, 321, 329, 332, $338,342,453-460)$.
} 
potrzeb dydaktycznych wykorzystać posiadaną wiedzę, tj. jakie zagadnienia włączyć do programu i gdzie je w nim umieścić. I wreszcie etap trzeci, który został wstępnie zarysowany $\mathrm{w}$ artykule A. Walkiewicz, wykonanie, czyli przygotowanie do prezentacji na lekcji, także wymagające namysłu, m.in. nad metodą pracy czy typem ćwiczeń.

Wybrana w tym opracowaniu perspektywa opisu zjawisk językowych, polegająca na wiązaniu składni i słowotwórstwa, jest osadzona w gramatyce strukturalnej o podstawach formalnych. Bezpośrednio odwołujemy się do wyników prac D. Buttler („Związki syntaktyczne”, „Derywacja słowotwórcza" i Innowacje 57-82) i J. Puzyniny (145-155). Bierzemy pod uwagę także nowsze opracowania, należące do szeroko rozumianego paradygmatu strukturalistycznego, w szczególności koncepcję jednostki języka oraz ustalenia związane $\mathrm{z}$ automatycznym przetwarzaniem języka w ramach przygotowywania Stownika walencyjnego języka polskiego „,Walenty” (Hajnicz i Nitoń).

Na siatkę pojęć z zakresu słowotwórstwa składają się terminy wykorzystywane $\mathrm{w}$ klasycznym strukturalistycznym opisie, przedstawionym przez R. Grzegorczykową i J. Puzyninę (361-388). W opisie odwołujemy się również do pojęcia jednostki leksykalnej, które rozumiemy tak, jak w pracach A. Bogusławskiego („O zasadach” i „Jednostki języka”). Całość informacji o łączliwości składniowej danej jednostki będziemy nazywać zgodnie z tradycją - jej schematem składniowym (Inny stownik XXX). Miejsca walencyjne są w nim sygnalizowane formami zaimków, przyimkiem lub spójnikiem. Do notowania alternatywnej realizacji danego miejsca jest stosowany znak ,/”, znak „_" zastępuje niewyrażoną jednostkę leksykalną w modelu schematu składniowego właściwego grupie jednostek leksykalnych, a poszczególne miejsca walencyjne są oddzielane znakiem „,", por. zdolność kogo + czego/do czego/żeby coś zrobić, kto uderzy czym + w co/ $\mathrm{o} \mathrm{co} / \mathrm{co}$.

Kluczowym pojęciem przedstawianego opracowania jest derywacja składniowa, termin pochodzący z prac D. Buttler, oznaczający „tworzenie konstrukcji składniowych derywatu dewerbalnego, rzadziej odprzymiotnikowego - na wzór modelu rekcji podstawy” (Buttler, „Derywacja słowotwórcza" 59). W późniejszej pracy Buttler, a za nią także inni autorzy (Wiśniewski 243-247), mówi raczej o dziedziczeniu werbalnej rekcji przez derywat, czyli ,zachowywaniu przy derywacie konstrukcji składniowej podstawy" (Buttler, Innowacje 58). Jako że rekcja odnosi się tylko do takich związków składniowych, które mają wykładniki formalne (wymaganie 
przypadka o określonej wartości lub przyimka o określonej postaci leksykalnej), w niniejszym opracowaniu - by nie zawężać przedmiotu obserwacji - zamiast o rekcji jednostki będziemy mówić o jej związkach składniowych lub łączliwości składniowej, a także o otwieraniu pozycji (miejsc) składniowych o określonej realizacji formalnej. Z kolei zjawisko dziedziczenia właściwości składniowych będziemy nazywać także powielaniem właściwości składniowych lub analogią składniową.

\section{DZIEDZICZENIE WŁAŚCIWOŚCI SKŁADNIOWYCH PRZEZ DERYWATY JAKO PRZEDMIOT BADAŃ JĘZYKOZNAWCZYCH ${ }^{3}$}

Systematyczne badania na temat dziedziczenia właściwości składniowych przez derywaty zaczęto prowadzić w połowie lat 50 . XX wieku (zob. Prokopovich 22-23). W językoznawstwie polonistycznym problem, który zaistniał za sprawą artykułu Z. Rysiewicza „O derywacji w składni”“, został rozwinięty wiele lat później m.in. dzięki badaniom J. Puzyniny (Puzynina) i D. Buttler („Związki syntaktyczne”, „Derywacja słowotwórcza” i Innowacje). Kwestia dziedziczenia związków składniowych w ramach derywacji lub w związku z budową morfologiczną jest obecna także w pracy M. Szupryczyńskiej, a $\mathrm{z}$ nowszych - w monografii M. Wiśniewskiego. Badacze analizowali zakres powielania związków składniowych, regularność ich przekształceń, a także czynniki sprzyjające zachowaniu związków oraz wpływające na ich utratę.

Bardzo interesujący jest z kolei najnowszy nurt badań, prowadzonych w ramach językoznawstwa komputerowego, a więc wspomaganych narzędziami informatycznymi. Zagadnienie powielania i zmiany związków składniowych jednostek pozostających $\mathrm{w}$ relacjach derywacyjnych nabiera bowiem nowego wymiaru. Wykorzystanie obszernych danych empirycznych zgromadzonych $\mathrm{w}$ korpusach tekstów oraz przygotowywanie i testowanie informatycznych narzędzi do przetwarzania danych językowych daje możliwość jakościowego i ilościowego weryfikowania wyników wcześniejszych badań, a także ich uzupełniania. Do ciekawszych obserwacji w tym zakresie

\footnotetext{
${ }^{3}$ Ze względu na ograniczoną objętość artykułu pominięte zostało przedstawienie innych zagadnień z dorobku polskiego słowotwórstwa końca XX i początku XXI wieku. Odsyłamy czytelnika do syntezy autorstwa K. Kleszczowej.

${ }^{4}$ Informacja pochodzi z artykułu D. Buttler „Derywacja słowotwórcza” 59.
} 
należy zaliczyć ujawnienie większej regularności zmian składniowych następujących w trakcie derywacji, niż wynikałoby z wcześniejszych ustaleń (Czelakowska; Hajnicz; Hajnicz i Bartosiak).

Należy także podkreślić, że obecność lub brak analogii składniowych między wyrazem podstawowym a pochodnym jest efektem działania antagonistycznego mechanizmu: zachowywania relacji semantycznej z podstawą w sposób pełny lub częściowy przy jednoczesnym zachodzeniu zmiany formalnej (różnica budowy morfologicznej, wynikająca z zastosowania rozmaitych formantów derywacyjnych i ich kombinacji, zmiana kategorii gramatycznych lub ich wartości, zmiana klasy gramatycznej, co pociąga za sobą zmianę funkcji składniowych). Badania potwierdziły, że zachowanie regularnego związku semantycznego derywatu z podstawą jest czynnikiem sprzyjającym analogii na płaszczyźnie składniowej, ale jej nie przesądza. Równie ważny jest czynnik gramatyczny: przynależność do klasy gramatycznej, a w jej obrębie - zastosowany w derywacji formant (Buttler, „Derywacja słowotwórcza" 61-73; Innowacje 77-81).

Z punktu widzenia glottodydaktyki ważne jest, że zależności zachodzące między związkami składniowymi podstawy słowotwórczej a derywatu można porządkować na podstawie kryteriów formalnych uwzględniających (1) parametry słowotwórcze, takie jak: typ formantu, typ derywacji, produktywność modelu derywacyjnego, kategoria słowotwórcza - w powiązaniu z regularnością derywacji, a także (2) parametry składniowe: klasa gramatyczna bazy i derywatu - w powiązaniu z funkcją składniową, klasa dystrybucyjna bazowej jednostki ustalona na podstawie jej łączliwości składniowej. W ten sposób możliwe jest pokazywanie zróżnicowanej seryjności zjawiska.

\section{ZWIĄZKI MIĘDZY SŁOWOTWÓRSTWEM A SKŁADNIĄ - WYBRANE ZAGADNIENIA}

Poniższe zestawienie podstawowych informacji na temat związków między słowotwórstwem a składnią zostało przygotowane na podstawie wspomnianej w poprzednim punkcie literatury przedmiotu oraz badań własnych. Zastosowano następujące kryteria porządkowania materiału: związek motywacyjny lub jego brak, przynależność do tej samej klasy gramatycznej lub innej, a także typ formantu wykorzystanego w procesie derywacji (sufiksy, prefiksy, formanty paradygmatyczne). 


\subsection{AnAlOgie SKŁadniowe MięDZY JEDNOSTKAMI POWIĄZANYMI ZWIĄZKIEM MOTYWACJI SŁOWOTWÓRCZEJ}

Przegląd rozpoczynamy od prześledzenia dyspozycji składniowych jednostek powiązanych derywacyjnie. W centrum uwagi będzie kwestia powielania schematów składniowych bazy przez derywat. Ujmując to zjawisko ogólnie, mamy do czynienia z trzema typami korelacji schematów składniowych:

1) schematy wyrazu podstawowego i pochodnego są identyczne, por. kto zachęci kogo + do czego/aby/cytat i kto zachęca kogo + do czego/ aby/cytat, zgodny z czym i zgodnie z czym (zgodny z instrukcja i zgodnie $z$ instrukcja),

2) schematy wyrazu podstawowego i pochodnego są w całości rozbieżne, np. biegly w czym i biegle $\varnothing$ (biegly w liczeniu i liczyt biegle),

3) schematy wyrazu podstawowego i pochodnego są częściowo rozbieżne; rozbieżność ta może być:

a) ilościowa, tj. różnica dotyczy liczby otwieranych miejsc, por. biegły w czym i biegłość kogo + w czym, mily dla kogo/wobec kogo i milszy dla kogo/wobec kogo + niż kto/od kogo,

b) jakościowa: 1) zachowana jest liczba otwieranych miejsc, ale są różnice $w$ ich realizacji, np. kto otrzymal co + od kogo i otrzymanie czego + od kogo + przez kogo (3 miejsca, w tym 2 o innej realizacji), przesyłka (czynność - 'to, że kto przesyła') czego + przez kogo i przesyłka (obiekt 'to, co przesyła') czyja/kogo/od kogo $+\mathrm{z}$ czym (Przesytka zamówionego sprzętu przez firmę kurierska jest opóźniona i Otrzymatem Państwa przesytkę z zamówionym sprzętem), 2) następuje zmiana relacji składniowych: kto wspina się gdzie - kto formalnie jest podrzędnikiem czasownika, kto wspinający się gdzie - kto jest nadrzędnikiem imiesłowu,

c) zarazem ilościowa i jakościowa, np. kto administruje czym i administrator czego (Gmina administruje budynkami i Gmina jest administratorem budynków).

To, czy analogia składniowa jest pełna, częściowa czy też jej nie ma, jest warunkowane semantycznie i formalnie. $Z$ perspektywy nauczania języka polskiego warto podkreślić, że przynajmniej część zmian schematów składniowych jest przewidywalna, tj. można zaobserwować określone prawidłowości dziedziczenia związków składniowych oraz ich zmian. Zjawisko to przedstawimy najpierw w odniesieniu do derywacji zachodzącej w obrębie tej samej klasy gramatycznej, następnie - pomiędzy klasami. 


\subsubsection{WYRAZ MOTYWUJĄCY I MOTYWOWANY NALEŻĄ DO TEJ SAMEJ KLASY GRAMATYCZNEJ}

Przynależność do tej samej klasy gramatycznej sprzyja analogii składniowej, jednak o niej nie przesądza. Ważny jest bowiem równocześnie czynnik semantyczny: modyfikacja lub zmiana znaczenia derywatu w stosunku do znaczenia bazy nierzadko skutkuje także zmianą na płaszczyźnie formalnej.

Jeśli chodzi o derywaty czasownikowe, zmiany semantyczne są częściowo skorelowane $\mathrm{z}$ typem i funkcją formantu. Derywaty odczasownikowe tworzone poprzez wymianę sufiksów w tematach, w szczególności stanowiące niedokonany człon pary aspektowej, dysponują tym samym schematem składniowym co bazowy czasownik (Buttler, Innowacje 76; Wróbel 538), por. kto czyta co - kto czytuje co (czytać - czytywać), kto da komu + co - kto daje komu + co (dać - dawać), kto przyjmie co + od kogo - kto przyjmuje co + od kogo (przyjąc - przyjmować), kto uderzy czym $+\mathrm{w}$ co/ o co/co - kto uderza czym $+\mathrm{w}$ co/o co/co (uderzyć - uderzać). Dodajmy, że właściwość tę wykorzystują opracowania leksykograficzne, w których czasowniki różniące się jedynie wartością aspektu są opisywane łącznie w jednym haśle ${ }^{5}$. Pełna analogia składniowa jest także możliwa, gdy derywat jest tworzony prefiksem o funkcji modyfikacyjnej, w tym aspektowej, np. kto szyje co - kto uszyje co (Szupryczyńska 63; Buttler, Innowacje 76; Wróbel 538), lub postfiksem się, np. kto prosi o co i kto prosi się o co. Prefiksacja jest jednak takim mechanizmem, który raczej należy wiązać $\mathrm{z}$ niepełną analogią składniową bazy i derywatu. Zdaniem D. Buttler (Innowacje 78) grupa przedrostków zmieniających i znaczenie, i składnię derywatu jest liczna. Jeśli prześledzimy dyspozycje składniowe czasowników prefiksalnych utworzonych od tej samej podstawy słowotwórczej, to zauważymy zarówno zmienność schematów, jak i ich ograniczoną seryjność. Zjawisko ilustrujemy na przykładzie derywatów czasownika budować w znaczeniu 'tworzyć obiekty, budowle', zob. Tabelę 1.

Zmiany jakościowe schematów składniowych obserwujemy także w grupie derywatów odczasownikowych tworzonych za pomocą postfiksu się. W grę wchodzi np. substytucja biernika przez dopełniacz, por. kto trzyma co - kto trzyma się czego (trzyma linę - trzyma się liny), biernika przez grupę $\mathrm{w}+\mathrm{kim} / \mathrm{czym}$, np. kto kocha kogo - kto kocha się w kim, kto ćwiczy co - kto ćwiczy się w czym, biernika przez grupę z + czego, np. kto umyje

\footnotetext{
${ }^{5}$ Słowniki w całości elektroniczne odchodzą od tej praktyki i sufiksalne człony par aspektowych opisują w odrębnych hasłach (Wielki słownik).
} 
co - kto umyje się z czego. Więcej tego rodzaju modyfikacji wraz z przykładami przytacza E. Hajnicz (18-25).

Tabela 1. Schematy składniowe czasowników pochodnych od podstawy budować.

\begin{tabular}{|c|c|}
\hline $\begin{array}{l}\text { kto_co + z czego }+ \text { komu/d dla kogo + gdzie } \\
\text { z czego - materiał }\end{array}$ & $\begin{array}{l}\text { budować, pobudować, wybudować } \\
\text { Jan na wsi buduje / pobuduje/ wybuduje dom z cegły dla } \\
\text { swojej córki. }\end{array}$ \\
\hline $\begin{array}{l}\text { kto_co + z czego / po czym } \\
\text { z czego - stan wyjściowy }\end{array}$ & $\begin{array}{l}\text { odbudować, odbudowywać } \\
\text { Gmina odbuduje pałacyk po pożarze/ z ruiny. }\end{array}$ \\
\hline kto_ ${ } 0$ & $\begin{array}{l}\text { przebudować, podbudować, podbudowywać, } \\
\text { rozbudować, rozbudowywać } \\
\text { Znajomi przebudowali swój dom na wsi. }\end{array}$ \\
\hline kto__co + czym & $\begin{array}{l}\text { obudować, obudowywać, zabudować, zabudowywać } \\
\text { Deweloper starq kamienicę obudował nowymi blokami. } \\
\text { Zabuduj tę wnękę meblami. }\end{array}$ \\
\hline kto _ $c 0+$ do czego & $\begin{array}{l}\text { dobudować, dobudowywać } \\
\text { Do stadionu dobudujemy nowe trybuny. }\end{array}$ \\
\hline kto_ $c 0+$ nad czym & $\begin{array}{l}\text { nadbudować, nabudowywać } \\
\text { Architekt zabronił nadbudować piętro nad naszym } \\
\text { mieszkaniem. }\end{array}$ \\
\hline kto _ $\mathrm{co}+\mathrm{w}$ co/ do czego & $\begin{array}{l}\text { wbudować, wbudowywać } \\
\text { Instalację wbudujemy w ścianę. }\end{array}$ \\
\hline $\begin{array}{l}\text { kto_czego / co + gdzie } \\
\text { czego - dopełniacz partytywny }\end{array}$ & $\begin{array}{l}\text { nabudować } \\
\text { Sąiad nabudował w swoim ogródku budek i domków dla } \\
\text { ptaków. }\end{array}$ \\
\hline
\end{tabular}

Z bardzo regularnym oraz dobrze opisanym i w gramatykach, i w materiałach do nauczania języka polskiego jako obcego zjawiskiem ilościowej i jakościowej modyfikacji schematu składniowego derywatu mamy natomiast do czynienia w klasie przymiotników. Schematy składniowe przymiotników w stopniu wyższym wzbogacają się o jedną pozycję składniową, realizowaną przez grupę przyimkowo-nominalną niż + kto/co lub od kogo/ czego, która w stopniu najwyższym jest realizowana przez grupy $\mathrm{z}$ innym zestawem przyimków, np. z + kogo/czego, spośród + kogo/czego, wśród + kogo/czego, por. wesoly - weselszy niż koledzy - najweselszy $w$ grupie. Stopniowanie, jak wiadomo, jest mechanizmem sytuującym się na pograniczu fleksji i słowotwórstwa. Regularność morfologiczna znajduje więc odzwierciedlenie także w składni. 
Jako że w programie nauczania polszczyzny znajduje się kategoria nazw żeńskich, warto też wspomnieć o należącej do niej podkategorii tworzonej formantem paradygmatycznym poprzez zmianę rodzaju i wzoru odmiany z męskiego odmiennego na żeński nieodmienny, por. profesor - profesor, doktor - doktor, premier - premier. Co prawda nie mamy tu do czynienia ze zmianą schematu składniowego, ale z regularną zmianą dyspozycji składniowych derywatów, co skutkuje koniecznością dostosowania wartości rodzaju przymiotników rozwijających rzeczownik oraz - oczywiście - form czasownikowych, por. Wręczono medal najmtodszemu polskiemu profesorowi - Wręczono medal najmłodszej polskiej profesor.

\subsubsection{WYRAZ MOTYWUJĄCY I MOTYWOWANY NALEŻĄ DO INNYCH KLAS GRAMATYCZNYCH}

W tej części opracowania koncentrujemy się na rzeczownikowych derywatach odczasownikowych. Krótki komentarz dotyczy także rzeczowników odprzymiotnikowych, przysłówków odprzymiotnikowych oraz przymiotników odczasownikowych.

Przynależność derywatu do innej klasy gramatycznej powoduje zmianę podstawowych funkcji i dyspozycji składniowych jednostki, co pociąga różnice także w obrębie schematów składniowych. Część zmian to kategorialne wymiany określonych typów podrzędników. Jak wiadomo, biernikowy podrzędnik czasownika przy rzeczowniku bezwyjątkowo jest zastępowany przez dopełniacz, a zamiast z przysłówkami odprzymiotnikowymi (jakościowymi) rzeczownikowe derywaty odczasownikowe łączą się z przymiotnikami, por. szybko biegać - szybkie bieganie - szybki bieg (Puzynina 150; Buttler, Innowacje 59; Hajnicz i Bartosiak 75).

Odczasownikowe derywaty rzeczownikowe oraz przymiotnikowe nie łączą się także z mianownikiem. Jeśli chodzi o pozycję przyrzeczownikową, mianownik przyczasownikowy jest przekształcany rozmaicie, w zależności od kategorii słowotwórczej, formantu wykorzystanego do utworzenia derywatu oraz pełnionej roli semantycznej. Wpływ ostatniego czynnika szczegółowo pokazuje zestawienie przedstawione przez E. Hajnicz i T. Bartosiaka (79-80). W sumie, jak ustalili wspomniani autorzy, w grę wchodzi około 20 różnych realizacji formalnych. Jak wiadomo, dla rzeczownikowych nazw czynności regularnie utworzonych od czasowników (substantiva verbalia, formanty -nie, -enie, -cie) jest to przede wszystkim dopełniacz oraz konstrukcja przez kogo/co, por. Jan odszedt - odejście Jana, Jan kapie 
dziecko - kapanie dziecka przez Jana. Przy rzeczownikach będących nazwami czynności utworzonymi mniej regularnie (substantiva deverbalia, różne sufiksy i formanty paradygmatyczne) mianownik jest rzadziej formalizowany za pomocą konstrukcji przez kogo/co (por. kolega pochwalit mój samochód - pochwała mojego samochodu przez kolegę). Częstszą formalizacją jest fraza dzierżawcza z przymiotnikiem lub rzeczownikiem w dopełniaczu, por. ja pracuje - moja praca, Jan awansowat - awans Jana, ludzie się denerwuja - ludzkie zdenerwowanie.

Jeśli chodzi o eliminowanie przy rzeczowniku innych podrzędników przyczasownikowych, na pierwszym miejscu należy umieścić bezokolicznik. Łączliwość z bezokolicznikiem w ogóle nie jest typowa dla rzeczownika. Współcześnie tylko około 40 rzeczowników tworzy konstrukcje z bezokolicznikiem (Gębka-Wolak 58-63). Co ciekawe, przeważnie nie jest to łączliwość dziedziczona po bazowym czasowniku. O przejmowaniu tej łączliwości można bowiem mówić jedynie w odniesieniu do kilku jednostek, tj. chęć, odwaga, polecenie, potrzeba, przykazanie, rozkaz, zamiar. Należy przy tym podkreślić, że dodatkowym warunkiem przyłączenia bezokolicznika jest użycie rzeczownika w kontekście konkretnej jednostki czasownikowej, najczęściej mieć, por. Odważyt się dokończyć zadanie - Miat odwage dokończyć zadanie - *Wykazat się odwaga dokończyć zadanie. $\mathrm{Z}$ kolei podrzędniki celownikowe i narzędnikowe są zachowywane przez gerundia. Inne rzeczowniki odczasownikowe często w ogóle ich nie przyłączają, a analogiczna treść jest wyrażana za pomocą konstrukcji z przyimkiem, por. Dzieci sprzeciwity sie rodzicom - sprzeciwienie się dzieci rodzicom - sprzeciw dzieci wobec rodziców, Zachwycamy się zadbanym ogrodem - nasze zachwycanie się zadbanym ogrodem - nasz zachwyt nad zadbanym ogrodem.

Z kolei przyczasownikowe konstrukcje przyimkowo-nominalne są zdecydowanie częściej powielane przez derywaty rzeczownikowe, dotyczy to zwłaszcza nazw czynności: przez gerundia regularnie, a przez inne derywaty $\mathrm{z}$ ograniczeniami, por. rozwodzić się z mężem - rozwód z mężem, trenować ze specjalista - trening ze specjalista, rejestrować się do lekarza - rejestracja do lekarza, wnioskować do wojewody - wniosek do wojewody, przewodzić w Unii Europejskiej - przewodnictwo w Unii Europejskiej, wygrać $w$ Lotto - wygrana $w$ Lotto. Tego rodzaju analogie zdarzają się także w innych kategoriach, np. nazw wykonawców czynności, por. skakać do wody - skoczek do wody (Buttler, „Związki syntaktyczne” 220; Innowacje 60). Należy ponadto podkreślić, że w pozycjach przyrzeczownikowych 
możliwych jest więcej i bardziej zróżnicowanych formalnie wariantów realizacyjnych z przyimkami niż przy odpowiednich czasownikach (zob. Hajnicz i Bartosiak 83), por. kto recenzuje co - czyja recenzja czego/na temat czego/w sprawie czego/w zakresie czego/z zakresu czego/z czego, co podgrzewa co - podgrzewacz czego/do czego/na co, co otwiera co - otwieracz czego do czego/od czego.

Rzeczowniki mogą także dziedziczyć łączliwość z podrzędnikami przyimkowo-rzeczownikowymi również po motywujących je przymiotnikach. $\mathrm{Na}$ taką prawidłowość zwrócił uwagę M. Wiśniewski po przebadaniu rzeczowników będących odprzymiotnikowymi nazwami cech, por. wściekły na kogo + za co - wściekłość na kogo + za co, lojalny wobec kogo/względem kogo/ w stosunku do kogo - lojalność wobec kogo/względem kogo/w stosunku do kogo (Wiśniewski 243-247). Co więcej, z analizy materiału wynika, że ok. $80 \%$ badanego zbioru rzeczowników ma schematy składniowe w całości powielające wymagania bazowych przymiotników. Powielanie nie dotyczy natomiast podrzędnika bezokolicznikowego, por. zdolny do czego/co zrobić - zdolność czego/do czego. Celownikowe rozwinięcia przymiotników są zaś przeważnie substytuowane przy rzeczownikach przez grupy przyimkowo-rzeczownikowe wobec kogo/dla kogo, por. wdzięczny komu - wdzięczność dla kogo/wobec kogo.

Z kolei z wstępnego porównania schematów przymiotników i ich przysłówkowych derywatów wynika, że - przy zachowaniu analogicznego znaczenia - możliwe jest dziedziczenie łączliwości z kilkunastoma przyimkami, np. $\mathrm{z}+$ czym, np. zgodny z sumieniem - zgodnie z sumieniem, do czego/ w stosunku do czego/wobec czego/względem czego, np. adekwatny do oryginatu - adekwatnie do oryginatu, od czego, np. zależny od oceny - zależnie od oceny. Zdarza się jednak, że przymiotnik i przysłówek nie różnią się znaczeniem, a mimo to nie łączą się z tym samym przyimkiem, por. Jan byt daleki od poparcia propozycji syna - Janowi byto daleko do poparcia propozycji syna. Kwestia dziedziczenia związków składniowych przymiotników przez przysłówki wymaga jednak dalszych systematycznych badań.

Dużą regularność w zakresie dziedziczenia schematów składniowych wykazują natomiast imiesłowy przymiotnikowe o znaczeniu czasownikowym. Imiesłowy czynne poza mianownikiem zachowują wszystkie wymagania bazowego czasownika, analogia dotyczy także rozwinięć luźnych, o charakterze okolicznikowym, por. Anna doskonale tlumaczy artykuty naukowe z polskiego na angielski - doskonale tlumaczaca artykuty naukowe z polskiego na angielski. Przy imiesłowach biernych dochodzi - jak wiadomo - 
do regularnej zmiany w planie semantycznym, co skutkuje przekształceniami pozycji podmiotowej i dopełnieniowej i ich realizacji, por. Emeryt codziennie wyprowadza psa do lasu - pies codziennie wyprowadzany do lasu przez emeryta. Zjawisko to jest dobrze opisane w materiałach do nauczania polszczyzny. Inne przymiotnikowe derywaty czasownika także mogą dziedziczyć wymagania podstawy słowotwórczej. Skala regularności analogii składniowej (poza regularną eliminacją mianownika) jest jednak zróżnicowana, powiązana z czynnikami semantycznymi, a więc trudniejsza do kategoryzowania, por. kto wierzy komu - wierny komu, kto skłania się do czego/żeby - skłonny do czego/co zrobić, kto zazdrości komu + czego zazdrosny o co (Buttler, Innowacje 61-72).

\subsection{PowiązANiA INNEgo RODZAJU}

Poza omówionymi wyżej powiązaniami schematów składniowych podstaw słowotwórczych i derywatów związki między słowotwórstwem a składnią widoczne są w zależnościach między budową słowotwórczą jednostki a jej łączliwością. Dotychczas ujawnione prawidłowości dotyczą wpływu przedrostka.

W materiałach do nauczania języka polskiego jako obcego zwraca się uwagę na korelacje przedrostka i przyimka, na przykład w związku z omawianiem czasowników ruchu. Trzeba jednak pamiętać, że serie typu dojechać do domu, podjechać pod szkote są krótkie, a użycie przyimka skorelowanego nie wyklucza użycia $\mathrm{z}$ tym samym czasownikiem innych przyimków, co na potrzeby nauczania starała się uporządkować I. Słaby-Góral (278-279).

Jak wynika z opracowań gramatycznych, na zmianę własności syntaktycznych czasownika szczególny wpływ mają przedrostki na- oraz do-, które, jak pisze E. Hajnicz (16), a wcześniej m.in. M. Szupryczyńska (6667), narzucają argumentowi partytywność, co wiąże się z użyciem dopełniacza (niekiedy alternującego z biernikiem), który nie jest używany w odpowiednich konstrukcjach bezprzedrostkowych, por. dorobić soku/sok robić sok, dodrukować pieniędzy/pieniadze - drukować pieniadze, nakroić chleba - kroić chleb, napiec ciastek - piec ciastka. Podobne właściwości, ale o mniejszym zakresie działania, wykazują przyrostki nad-, od-, przy(Szupryczyńska 66-67).

W literaturze odnotowano również korelację polegająca na rozszerzeniu schematu czasownika z przedrostkiem na-, o-, ob-, od-, prze-, roz-, wy- 
o miejsce dla konstrukcji nominalnej biernikowej, z którą nie łączył się bazowy czasownik, por. kto jedzie - kto najedzie kogo/co, kto kłamie - kto okłamie kogo, co rośnie - co obrośnie co, kto biegnie - kto przebiegnie co, kto pracuje - kto rozpracuje kogo/co, kto płacze - kto wypłacze co (Szupryczyńska 69-70). Poszczególne serie takich par czasownikowych są jednak krótkie, kilkuelementowe. Jeszcze krótsze są serie z przedrostkami prze-, wy-, w których dodanie przedrostka skutkuje zmianą konstrukcji z przyimkiem na konstrukcję biernikiem, np. kto głosuje na kogo - kto przegłosuje kogo, kto walczy o prawa - kto wywalczy prawa (Szupryczyńska 71).

$\mathrm{Z}$ gramatycznego punktu widzenia interesującym zjawiskiem jest korelacja przedrostka $\mathrm{z}$ możliwością zerowania dopełnienia (Hajnicz 14), co $\mathrm{w}$ literaturze jest nazywane alternacją porzucenia dopełnienia (por. angielski termin object drop). Alternacja polega na tym, że użycie określonego przedrostka, w polszczyźnie jest to po-, umożliwia zbudowanie gramatycznie poprawnego zdania $\mathrm{z}$ pominiętym dopełnieniem, co nie jest możliwe, gdy zdanie jest konstytuowane przez zbliżony znaczeniowo czasownik, ale o innej budowie morfologicznej, por. a) Piotr posprzatat pokój oraz Piotr posprzatat i b) Piotr sprzatnąt pokój oraz eliptyczne Piotr sprzątnąt. Zjawisko ma podłoże semantyczne. Dotyczy bowiem czasowników ze szczegółowo scharakteryzowanym argumentem obiektowym wbudowanym $\mathrm{w}$ strukturę semantyczną czasownika. Stąd też - zdaniem Hajnicz (14) - możliwe jest usunięcie dopełnienia przy czasowniku pozmywać, a niemożliwe przy czasowniku posktadać.

Zasygnalizowane $\mathrm{w}$ tym punkcie zjawiska $\mathrm{z}$ pogranicza słowotwórstwa i składni są idiosynkratyczne, dlatego trudno je umieszczać w programach nauczania języka polskiego jako obcego. Warto natomiast zwracać na nie uwagę na lekcjach, w ramach poszerzania i utrwalania zasobu leksykalnego polszczyzny.

\section{UWAGA KOŃCOWA}

Jeśli chodzi o samo zjawisko związków między składnią a słowotwórstwem, przedstawiony przegląd materiału - z konieczności bardzo skrótowy - pokazuje, że semantyczna i formalna regularność derywacji skutkuje powielaniem schematu składniowego wyrazu motywującego przez wyraz motywowany, a ewentualne różnice dyspozycji składniowych są w znacz- 
nym stopniu przewidywalne. Regularność zjawiska ułatwia z kolei jego prezentację $\mathrm{w}$ ramach nauczania języka polskiego jako obcego. Większego namysłu wymaga natomiast zakres i sposób prezentacji zjawisk mniej seryjnych lub wręcz jednostkowych, których - jak pokazujemy wyżej - także nie brakuje. Kwestia ta zostanie rozwinięta w tekście A. Walkiewicz „Rozwiązania dydaktyczne". W tym miejscu, nawiązując do sformułowanego w literaturze glottodydaktycznej postulatu ujmowania słowotwórstwa w procesie dydaktycznym bardziej leksykalnie niż gramatycznie, ograniczymy się do zaproponowania, by w materiałach dydaktycznych informacje o schematach składniowych jednostek leksykalnych w większym stopniu niż obecnie podawać wprost, w postaci reguł dziedziczenia, schematów i ilustrujących je przykładów. Syntetyczną informację o podobieństwach i regularnych oraz nieregularnych różnicach dyspozycji składniowych można kodować za pomocą szeregów słowotwórczych ${ }^{6}$. W nauczaniu języka polskiego taki szereg musiałby być zorganizowany na podstawie kryterium dziedziczenia schematu składniowego, a nie pochodności. Technicznie może to wyglądać tak, że szereg (a) pokazywałby wspólne elementy schematu składniowego, szereg (b) - regularne przekształcenia, a szereg (c) - zmiany wymagań, jeśli takowe w gnieździe zachodzą, por.

1 (a) zależy, zależący, zależny, zależność, zależnie od kogo/czego,

1 (b) co zależy - zależność czego;

2 (a) zazdrości, pozazdrości, zazdroszczący, zazdroszczenie komu + czego,

2 (b) kto zazdrości, pozazdrości - zazdroszczenie przez kogo, zazdrość kogo,

2 (c) zazdrosny, zazdrość + o co.

\section{BIBLIOGRAFIA}

Bogusławski, Andrzej. „O zasadach rejestracji jednostek języka”. Poradnik Językowy, z. 8, 1976, ss. 356-364.

Bogusławski, Andrzej. „Jednostki języka a produkty językowe. Problem orzeczeń peryfrastycznych”. Z zagadnień słownictwa współczesnego języka polskiego, red. Mieczysław Szymczak, Zakład Narodowy im. Ossolińskich, Wydawnictwo Polskiej Akademii Nauk, 1978, ss. 17-30.

\footnotetext{
${ }^{6}$ Szereg albo łańcuch słowotwórczy to element gniazda słowotwórczego, to „każdy zbiór składający się z wyrazu hasłowego oraz wszystkich derywatów, bezpośrednio pochodnych od swoich podstaw na odpowiednich taktach derywacyjnych" (Jadacka 23). Do zobrazowania korelacji związków słowotwórczych ze składniowymi narzędzie to wykorzystał M. Wiśniewski (146 i in.).
} 
Buttler, Danuta. „Związki syntaktyczne rzeczowników dewerbalnych o znaczeniu podmiotowym”. Poradnik Językowy, z. 5, 1967, ss. 219-228.

Buttler, Danuta. „Derywacja słowotwórcza a derywacja syntaktyczna”. Prace Filologiczne, 1969, ss. 59-76.

Buttler, Danuta. Innowacje składniowe współczesnej polszczyzny. Państwowe Wydawnictwo Naukowe [PWN], 1976.

Czelakowska, Anna. „Nazwy czynności i nazwy rezultatów czynności w derywacji semantycznej”. LingVaria, nr 2, 2019, ss. 73-92.

Florczak, Jacek. Językoznawcze aspekty modelu kształtowania kompetencji języka obcego. Wydawnictwo Uniwersytetu Łódzkiego, 2010.

Gaze, Mateusz. „Związki między słowotwórstwem a grafią w nauczaniu języka polskiego jako obcego". PLEJ_2 czyli PsychoLingwistyczne Eksploracje Językowe, red. Olga Majchrzak, Wydawnictwo Uniwersytetu Łódzkiego, 2013, ss. 231-247.

Gaze, Mateusz. „Rola słowotwórstwa w przyswajaniu innych podsystemów języka”. Interdyscyplinarność $i$ wielowymiarowość nauk filologicznych. Philological Studies: Interdisciplinary and Multidimensional Approaches, red. Dorota Gonigroszek i Agnieszka Stanecka, Naukowe Wydawnictwo Piotrkowskie przy Filii Uniwersytetu Jana Kochanowskiego, 2016, ss. 173-186.

Gębka-Wolak, Małgorzata. Pozycje składniowe frazy bezokolicznikowej we wspótczesnym zdaniu polskim. Wydawnictwo Naukowe Uniwersytetu Mikołaja Kopernika, 2011.

Grzegorczykowa, Renata, i Jadwiga Puzynina. „Problemy ogólne słowotwórstwa”. Gramatyka wspótczesnego języka polskiego, red. Renata Grzegorczykowa, Roman Laskowski i Henryk Wróbel, Wydawnictwo Naukowe PWN, 1998, ss. 361-388.

Hajnicz, Elżbieta. Dobór czasowników do badań przy tworzeniu słownika semantycznego czasowników polskich. Prace IPI PAN, 2007.

Hajnicz, Elżbieta., i Tomasz Bartosiak. „Walencja rzeczowników w słowniku Walenty i sposób jej powiązania z walencją odpowiednich czasowników”. Prace Filologiczne, 2018, ss. 71-85.

Hajnicz, Elżbieta, i Bartłomiej Nitoń, „Instrukcja dostępu do słownika walencyjnego Walenty za pośrednictwem programu Slowal”, CLARIN, clarin-pl.eu/wp-content/uploads/2017/05/ instrukcja_uzytkownika_Walentego.pdf. Dostęp 1.05.2019.

Inny słownik języka polskiego, red. Mirosław Bańko, Wydawnictwo Naukowe PWN, 2000.

Jadacka, Hanna. Rzeczownik polski jako baza derywacyjna. Wydawnictwo Naukowe PWN, 1995.

Janowska, Aleksandra. „O swoistości derywacji na tle innych sposobów nominacji”. Sztuka czy rzemiosto? Nauczyć Polski i polskiego, red. Aleksandra Achtelik i Jolanta Tambor, Wydawnictwo Gnome, 2007, ss. 28-34.

Janowska, Aleksandra. „Z pogranicza słowotwórstwa. O «podstawach związanych»”. Sztuka i rzemiosto. Nauczyć Polski i polskiego. Tom 2, red. Aleksandra Achtelik, Małgorzata Kita i Jolanta Tambor, Wydawnictwo Gnome, 2010, ss. 16-21.

Janowska, Aleksandra. „Złożoność derywacji czasownikowej z punktu widzenia glottodydaktyki (na materiale czasowników odczasownikowych)". Sztuka to rzemiosło. Nauczyć Polski i polskiego. Tom 3, red. Aleksandra Achtelik i Jolanta Tambor, Wydawnictwo Gnome, 2013, ss. 20-29.

Kaleta, Zofia. Gramatyka języka polskiego dla cudzoziemców. Wydawnictwo Uniwersytetu Jagiellońskiego, 1995. 
Kleszczowa, Krystyna. „Polskie badania słowotwórcze u progu XXI wieku”. Językoznawstwo $w$ Polsce. Kierunki badań i perspektywy rozwoju, red. Maciej Grochowski, BEL Studio, ss. 125-137.

Pastuchowa, Magdalena. „Rola słowotwórstwa w kształtowaniu kompetencji językowej cudzoziemców". Sztuka i rzemiosto. Nauczyć Polski i polskiego. Tom 2, red. Aleksandra Achtelik, Małgorzata Kita i Jolanta Tambor, Wydawnictwo Gnome, 2010, ss. 9-15.

Pastuchowa, Magdalena. „Słowotwórstwo - sposób na nazywanie świata czy część systemu gramatycznego". Sztuka to rzemiosło. Nauczyć Polski i polskiego. Tom 3, red. Aleksandra Achtelik i Jolanta Tambor, Wydawnictwo Gnome, 2013, ss. 9-19.

Prokopovich, Nikolay. Voprosy sintaksisa russkogo jazyka. Vysshaja shkola, 1974 [Прокопович, Николай. Вопросы синтаксиса русского языка. Высшая школа, 1974].

Puzynina, Jadwiga. Nazwy czynności we współczesnym języku polskim. Państwowe Wydawnictwo Naukowe [PWN], 1969.

Rysiewicz, Zygmunt. „O derywacji w składni”. Biuletyn Polskiego Towarzystwa Językoznawczego, 1936, ss. 47-53.

Seretny, Anna, i Wiesław Stefańczyk. „Między gramatyką a słownikiem - słowotwórstwo w perspektywie glottodydaktycznej”. Postscriptum Polonistyczne, nr 2, 2015, ss. 45-61.

Słaby-Góral, Iwona. „Czas przypadka w języku polskim, czyli próba wyjaśnienia polisemii wybranych przyimków". Edukacja Międzykulturowa. Forum dydaktyczne, red. Anna Rabczuk, Uniwersytet Warszawski, 2013, ss. 277-292.

Szupryczyńska, Maria. Syntaktyczna klasyfikacja czasowników przybiernikowych. Państwowe Wydawnictwo Naukowe [PWN],1973.

Wielki słownik języka polskiego, red. Piotr Żmigrodzki, Polska Akademia Nauk, WSJP Wielki słownik języka polskiego, wsjp.pl. Dostęp 26.01.2021.

Wiśniewski, Marek. Dystrybucyjne wtaściwości odprzymiotnikowych nazw cech we wspótczesnej polszczyźnie. Wydawnictwo Uniwersytetu Mikołaja Kopernika, 2005.

Wróbel, Henryk. „Czasownik”. Gramatyka współczesnego języka polskiego, red. Renata Grzegorczykowa, Roman Laskowski, Henryk Wróbel, Wydawnictwo Naukowe PWN, 1998, ss. 536-583.

\section{SŁOWOTWÓRSTWO A SKŁADNIA \\ W NAUCZANIU JĘZYKA POLSKIEGO JAKO OBCEGO \\ CZĘŚĆ 1. WPROWADZENIE TEORETYCZNE}

Streszczenie

Artykuł dotyczy nauczania języka polskiego jako obcego. Stanowi pierwszy z dwóch tekstów poświęconych nauczaniu słowotwórstwa z perspektywy jego związku ze składnią. Wiedza na ten temat jest przydatna do budowania zdań i dłuższych wypowiedzi oraz dokonywania w ich ramach przekształceń o funkcji stylistycznej. W opracowaniach kierowanych do uczących się języka polskiego jako obcego informacje o analogii składniowej wyrażeń powiązanych relacjami słowotwórczymi są rozproszone, co utrudnia zorientowanie się w zakresie i stopniu regularności zjawiska. Przedstawiany artykuł wiedzę tę uzupełnia i porządkuje na podstawie dorobku gramatyki strukturalnej o podstawach formalnych oraz badań własnych. Pokazuje zróżnicowaną seryjność zjawiska dziedziczenia schematu składniowego: od identyczności schematów, przez częściową zbieżność po całkowitą zmianę walencji, tj. liczby otwieranych miejsc i ich realizacji. W tekście 
zwrócono także uwagę na to, że w ramach klas i podklas gramatycznych oraz zastosowanych formantów słowotwórczych zakres dziedziczenia składni jest do pewnego stopnia przewidywalny.

Słowa kluczowe: nauczanie języka polskiego jako obcego; słowotwórstwo a składnia; walencja; dziedziczenie schematu składniowego.

\section{THE RELATIONSHIP BETWEEN WORD-FORMATION AND SYNTAX IN TEACHING POLISH AS A FOREIGN LANGUAGE}

\section{PART 1: THEORETICAL PRELIMINARIES}

\section{Su m m a r y}

This paper is the first of two devoted to teaching word-formation, based on the existing correlations between derivation and syntax. This kind of knowledge has proved to be essential for building longer structures and performing stylistic operations on texts. Information on the syntactic inheritance of derived language units is scattered throughout the literature, however, making it difficult for teachers and students to grasp the actual range and regularity of this phenomenon. This article, based on formal structural grammar methods, systemises this data and shows the various degrees of syntactic inheritance, ranging from identical syntactic structures, which inherit only part of the syntactic properties of the base, to a complete change of valency. It also points to the fact that the range of syntactic analogy is, to some extent, predictable, depending on the part of speech and on the word-formation mechanism.

Keywords: teaching PFL; word-formation and syntax; valency; syntactic inheritance. 